IZA DP No. 6192

The Evolution of the Racial Gap in Education and the Legacy of Slavery

Graziella Bertocchi

Arcangelo Dimico

December 2011 


\title{
The Evolution of the Racial Gap in Education and the Legacy of Slavery
}

\author{
Graziella Bertocchi \\ University of Modena, \\ CEPR, CHILD and IZA
}

Arcangelo Dimico

Queen's University of Belfast

\section{Discussion Paper No. 6192 December 2011}

\author{
IZA \\ P.O. Box 7240 \\ 53072 Bonn \\ Germany \\ Phone: +49-228-3894-0 \\ Fax: +49-228-3894-180 \\ E-mail: iza@iza.org
}

\begin{abstract}
Any opinions expressed here are those of the author(s) and not those of IZA. Research published in this series may include views on policy, but the institute itself takes no institutional policy positions.

The Institute for the Study of Labor (IZA) in Bonn is a local and virtual international research center and a place of communication between science, politics and business. IZA is an independent nonprofit organization supported by Deutsche Post Foundation. The center is associated with the University of Bonn and offers a stimulating research environment through its international network, workshops and conferences, data service, project support, research visits and doctoral program. IZA engages in (i) original and internationally competitive research in all fields of labor economics, (ii) development of policy concepts, and (iii) dissemination of research results and concepts to the interested public.
\end{abstract}

IZA Discussion Papers often represent preliminary work and are circulated to encourage discussion. Citation of such a paper should account for its provisional character. A revised version may be available directly from the author. 
IZA Discussion Paper No. 6192

December 2011

\section{ABSTRACT \\ The Evolution of the Racial Gap in Education and the Legacy of Slavery*}

We study the evolution of racial educational inequality across US states from 1940 to 2000 . We show that throughout this period, despite evidence of convergence, the racial gap in attainment between blacks and whites has been persistently determined by the initial gap. We obtain these results with 2SLS estimates where slavery is used as an instrument for the initial gap. The excludability of slavery is preliminarily established by instrumenting it with the share of disembarked slaves from the Trans-Atlantic Slave Trade. Using the same approach we also find that income growth is negatively affected by the initial racial gap in education and that slavery affects growth indirectly through this channel.

JEL Classification: J15, I24, N31, O11

Keywords: race, inequality, education, slavery, development

Corresponding author:

Graziella Bertocchi

University of Modena

Dipartimento di Economia Politica

Viale Berengario, 51

41121 Modena

Italy

E-mail: graziella.bertocchi@unimore.it

\footnotetext{
Generous financial support from the Fondazione Cassa Risparmio di Modena and the Italian University Ministry is gratefully acknowledged.
} 


\section{Introduction}

Among the several dimensions of inequality, racial inequality is a rather peculiar characteristic of American society, if compared to other countries at similar levels of development. Because of the crucial role played by human capital in determining earnings prospects, the unequal distribution of income between blacks and whites is in turn closely associated with the underlying racial gap in educational attainment. Over time, black-white gaps in schooling have actually decreased. ${ }^{1}$ At the same time, however, this trend has come to a halt in more recent decades, ${ }^{2}$ confirming the persistence of deeply-rooted racial disparities despite the observed process of convergence. These recent developments suggest that the dynamics of the racial gap in attainment follow path dependence, i.e., they are influenced by initial conditions.

To test the hypothesis that racial educational inequality persists over time and depends on its initial level, which can be measured from the year $1940,{ }^{3}$ would inevitably expose the empirical analysis to omitted variables and measurement errors bias leading to inconsistent estimates. To address this problem, in the search for suitable instruments, it is legitimate to look at the association between the racial gap in education in 1940 and past slavery. Collins and Margo (2006) narrate how in the aftermath of the Civil War the "legacies of slavery” determined extremely high rates of illiteracy among blacks. Margo (1990) documents how the obstacles subsequently encountered by black children in acquiring education represented the channels through which past slavery ended in inequalities which were still present at the eve of World War Two. Indeed the correlation between the racial educational gap in 1940 and the share of slaves over population in 1860 is extremely high: 0.90 and 0.81 at the high-school and bachelor level, respectively. However, to use past slavery as an instrument for the initial gap in education requires ascertaining its excludability, which may not be warranted in the presence of any direct effect on educational outcomes.

The goal of this paper is two-fold. First, we aim at obtaining consistent estimates of the persistency of the effect of the initial gap on subsequent educational disparities between whites and blacks. Second, we try to establish that past slavery - being a crucial determinant of the initial gap - stills plays a considerable role in American society.

\footnotetext{
${ }^{1}$ Collins and Margo (2006) document these progresses for the period before 1960, while Smith (1984) and Smith and Welch (1989) provide evidence for the 1940-1980 period, and Neal (2006) for the 1960-2000 period.

${ }^{2}$ Neal (2006) documents that among 26-30 years old, the racial educational attainment gap in 2000 is actually slightly larger than in 1990.

${ }^{3}$ State-level Census data are available from 1940 to 2000.
} 
We can present our empirical strategy and our results in two steps. First, we look at the determinants of the racial educational gap over the 1940-2000 period using a simple OLS estimator, with a focus on the potential effect of past slavery. This preliminary step reveals that slavery in 1860 does appear to influence the dependent variable only through the initial gap. This indirect effect of slavery therefore suggests that slavery may be a suitable instrument for the latter. However, omitted variables and measurement errors bias may once again be present in the relationship between slavery and the initial gap, yielding inconsistency of OLS and consequent under-estimation of the effect of the initial gap on subsequent inequality. Moreover, the excludability of slavery needs to be assured more formally. To address these problems, we use an instrument for slavery in 1860 which we construct on the basis of information on the Trans-Atlantic Slave Trade (TAST). In more detail, we use the ratio of disembarked slaves in any given state to the total number of slaves disembarked in the US during the TAST as an instrument for the state's slave share in 1860. The relevance of the instrument is assured by the high correlation between the two variables (almost 0.49). Its excludability can be defended on the ground that it is reasonable to expect that the impact of the share of disembarked slaves on contemporaneous racial educational inequality only runs through the effect on the slave share in 1860 and its subsequent influence on disenfranchisement and education policy. The resulting 2SLS estimates - where slavery is instrumented with the share of disembarked share - confirm the absence of a direct effect of slavery in 1860 on the racial educational gap and that slavery only affects the latter through the initial gap.

As a second step, we proceed by estimating the effect of the initial gap in 1940 on the subsequent evolution of educational inequality using a 2SLS estimator where past slavery in 1860 is employed as an instrument for the initial gap in 1940. This second step should provide a consistent estimate of the effect of the initial gap in education on the evolution of the racial inequality in education. While the relevance of the instrument is assured by its previously-reported high correlation with the initial gap, our results from the first step now also support its excludability, since in previous regressions we show that past slavery affects the educational gap only through the initial gap. The 2SLS estimates confirm the impact of the initial gap and thus the persistence of racial educational inequality. These results, taken together with the link we establish between initial gap and slavery, validate the conjecture that the origins of education inequality are indeed very deeply rooted throughout American history.

Once having established the nature of the link between past slavery and racial educational inequality, we turn to its potential association with income growth throughout the 1940-2000 period. Again we proceed in two steps. First, we show that slavery in 1860, again instrumented with 
the share of disembarked slaves resulting from the TAST, has no direct effect on growth. Second, we can use slavery in 1860 as an instrument for the initial educational gap and show that the latter exerts a consistent negative influence on growth. Thus, we find that slavery matters for growth but once again only indirectly and we identify this channel as racial educational inequality.

To sum up, we obtain consistent estimates of a persistent effect of the 1940 level of racial educational inequality both on subsequent racial educational inequality and income growth. We also find that past slavery still matters for both outcomes, not directly but indirectly through its influence on the initial gap in attainment between blacks and whites. In other words, those US states that relied more intensively on the use of slave labor still exhibit today larger racial disparities in education and lower growth, through a channel which is represented by the initial gap in attainment, i.e., through the transmission of human capital.

As a by-product of our investigation, we also establish that past slavery is a suitable instrument for the degree of educational inequality across US states still prevailing at the eve of World War Two, because it affects contemporaneous outcomes only through this indirect channel. Since previous work on the link between inequality and development has been plagued by reverse causality and omitted variables bias, this result is of independent interest and could be exploited in future research.

The paper is organized as follows. Section 2 summarizes the related literature. Section 3 presents the stylized facts and begins our empirical investigation on the determinants of the racial educational gap over the 1940-2000 period through OLS estimates. In Section 4 we illustrate our two-step instrumentation strategy to obtain consistent 2SLS estimates. Section 5 extends the analysis to the determinants of income growth. Section 6 derives our conclusion.

\section{Related Literature}

This work is related to an emerging literature which is focused on the long-term effect of slavery on the US economy and society. Building on Engerman and Sokoloff (2005), Nunn (2008a) finds that past slave use is negatively correlated with current economic development for a sample of US counties. ${ }^{4}$ Over the same sample, Bertocchi and Dimico (2011a) instead show that the main effect of past slavery is on current income inequality, while the effect on income is not robust to controls for structural differences across US states. They also suggest that the channel of transmission from

\footnotetext{
${ }^{4}$ Similar conclusions are reached by Mitchener and McLean (2003) and Lagerlöf (2005).
} 
slavery to inequality is human capital, since current income inequality is primarily influenced by slavery through the unequal educational attainment of blacks and whites. ${ }^{5}$ While racial educational inequality in Bertocchi and Dimico (20011a) is simply measured by years of schooling in the year 2000, in this paper we expand the investigation to a state-level panel dataset over the 1940-2000 period which contains specific information on educational attainment by race. This allows us to improve our understanding of the dynamics of racial inequality along the educational dimension.

A separate research line, which is also relevant to our approach, has focused on the impact of race on inequality. This work has documented that, since emancipation and especially since 1940, the average income of black Americans has increased greatly. Both the civil rights movement, through its impact on labor market discrimination, and the gradual closing of the human capital gap have been advanced as possible explanations of the observed trend (Heckman, 1990 and Margo, 1990). As mentioned in the introduction, the evolution of racial inequality in educational attainment has been illustrated by Smith (1984), Smith and Welch (1989), Margo (1990), and Collins and Margo (2006), and Neal (2006). ${ }^{6}$ The evidence collected by these authors document the evolution of racial differences both in the quality and the quantity of education. After the Civil War, AfricanAmericans had essentially no exposure to formal schooling, as a legacy of the extremely high rates of illiteracy that existed under slavery. The first generations of former slaves were able to complete far fewer years of schooling, on average, than whites and had access to racially segregated public schools, mostly in the South, where they received a qualitatively inferior education, even if compared to that received by Southern whites. ${ }^{7}$ Initially the combination of low educational attainment and inferior educational quality determined the persistence of large income gaps. Subsequently, however, the racial schooling gap declined, as successive generations of black children received more and better schooling, with an eventual impact on earnings. Overall, despite the initial conditions and the persistence of discrimination, the reported evidence on the evolution of educational differences, in a wide number of dimensions (such as literacy rates, years of educational attainment, spending per pupil, and returns to literacy), points to long-term convergence but also to persistence of the legacies of the past. ${ }^{8}$ Our contribution to this line of research is to provide

\footnotetext{
${ }^{5}$ For a sample of Mississippi counties, Bertocchi and Dimico (2011b) find that the legacy of slavery prevails over political institutions as the main force driving post-war development.

${ }^{6}$ See also Goldin and Margo (1992), Goldin (1998), and Goldin and Katz (1999).

${ }^{7}$ Naidu (2010) estimates the effect of the nineteenth century disenfranchisement laws for blacks in the South and finds that they are associated with a fall in black educational inputs and thus with low-quality Southern schooling. For Mississippi Bertocchi and Dimico (2011b) show that black disenfranchisement exerts a persistent and significant effect on the number of black teachers per black pupil and education expenditure for blacks in the subsequent decades, at least up to the 1950s. On school segregation in the US South see also Welch (1973), Orazem (1987), Card and Krueger (1992), and Fishback and Baskin (1991).

${ }^{8}$ A related stream of the literature has measured the long-term influence of family background. See for example Cameron and Heckman (2001) and Sacerdote (2005).
} 
consistent empirical estimates of the determinants of the evolution of racial educational inequality and to establish how it is linked to past slavery.

Finally, this paper is also related to the literature on the evolution of the US educational system and its effects on income distribution and growth. An exhaustive discussion of the topic is provided by Goldin and Katz (2001), who point to the expansion of secondary education in the twentieth century (the high-school movement) as the main determinant of the subsequent growth differentials between the US and Europe. Barro and Sala-i-Martin (1991), Jones (2001), Higgins et al. (2006), Aghion et al. (2009), and Galor et al. (2009) also view education as the main driver of economic growth across US states. However, while most of the literature on education and growth looks at the level of education, either as investment in human capital or schooling attainment, here we focus on the distribution of education across different races, i.e., on the racial dimension of educational inequality. $^{9}$

\section{The Determinants of the Racial Educational Inequality}

We start looking at the dynamics of racial inequality along the educational dimension using a panel of educational attainment across races for the US states in the 1940-2000 period. Table 1 shows the shares of whites and blacks with at least either a high-school education or a bachelor degree. Over the 1940-2000 period whites are on average more educated than blacks. The share of white population with at least a high-school level of education is above $60 \%$ against a $47 \%$ of black population. The gap between whites and blacks is even larger (in relative terms) when we consider the share of population with a bachelor degree (15.4\% against $8.8 \%)$. In this case the share of black population holding a bachelor degree is in mean $40 \%$ smaller than the corresponding white. In addition, the population in the North of the US seems to have a higher level of education both within the black and the white population.

\footnotetext{
${ }^{9}$ On the empirical links between inequality and growth in the US, see for example Partridge (1997), Panizza (2002), and Frank (2009).
} 
Table 1: Educational Attainment, by Race, 1940-2000

\begin{tabular}{|c|c|c|c|c|c|}
\hline \multicolumn{6}{|c|}{ All States } \\
\hline Variable & Obs & Mean & Std. Dev. & Min & Max \\
\hline High-School Diploma (Whites) & 297 & 60.2291 & 21.34998 & 16.37847 & 94.43 \\
\hline Bachelor Degree (Whites) & 297 & 15.42412 & 9.624878 & 2.813198 & 77.3 \\
\hline High-School Diploma (Blacks) & 297 & 47.18088 & 26.79546 & 2.594816 & 95.9 \\
\hline Bachelor Degree (Blacks) & 297 & 8.758676 & 6.594131 & .3484704 & 34.82 \\
\hline \multicolumn{6}{|c|}{ Northern States } \\
\hline Variable & Obs & Mean & Std. Dev. & Min & Max \\
\hline High-School Diploma (Whites) & 199 & 64.82332 & 20.23654 & 20.85144 & 94.43 \\
\hline Bachelor Degree (Whites) & 199 & 16.91558 & 10.25016 & 3.544309 & 77.3 \\
\hline High-School Diploma (Blacks) & 199 & 54.32846 & 25.12736 & 5.924223 & 95.9 \\
\hline Bachelor Degree (Blacks) & 199 & 10.1778 & 7.026015 & 1.125535 & 34.82 \\
\hline \multicolumn{6}{|c|}{ Southern States } \\
\hline Variable & Obs & Mean & Std. Dev. & Min & Max \\
\hline High-School Diploma (Whites) & 98 & 50.90004 & 20.58661 & 16.37847 & 86.31 \\
\hline Bachelor Degree (Whites) & 98 & 12.39555 & 7.375334 & 2.813198 & 34.73 \\
\hline High-School Diploma (Blacks) & 98 & 32.66692 & 24.17767 & 2.594816 & 78.95 \\
\hline Bachelor Degree (Blacks) & 98 & 5.876993 & 4.404805 & .3484704 & 20.29 \\
\hline
\end{tabular}

In Figure 1 (the two plots at the top) we show the time evolution of the educational gap between whites and blacks calculated as the ratio of the share of whites to the share of blacks with at least a high-school diploma (on the LHS) or a bachelor degree (on the RHS). The figure shows a sort of convergence in the share of population (belonging to the two groups) with a high-school education. The gap between the shares of whites and blacks holding a bachelor degree also decreases over time, but this seems to occur at a slower rate. In the two panels at the bottom of the figure we plot the educational gap against the initial educational gap. The panels show that those states which started with a larger gap are nowadays the ones which still have larger racial inequality in terms of education, both at the high-school (LHS) and the bachelor (RHS) level. Therefore, on the one hand we observe a sort of convergence across racial groups over the period (the two panels at the top). On the other hand there has been a sort of divergence across states such that the educational gap between racial groups has been absorbed faster in states which started with a lower gap (the two panels at the bottom). 
Figure 1: The Educational Gap between Whites and Blacks, 1940-2000
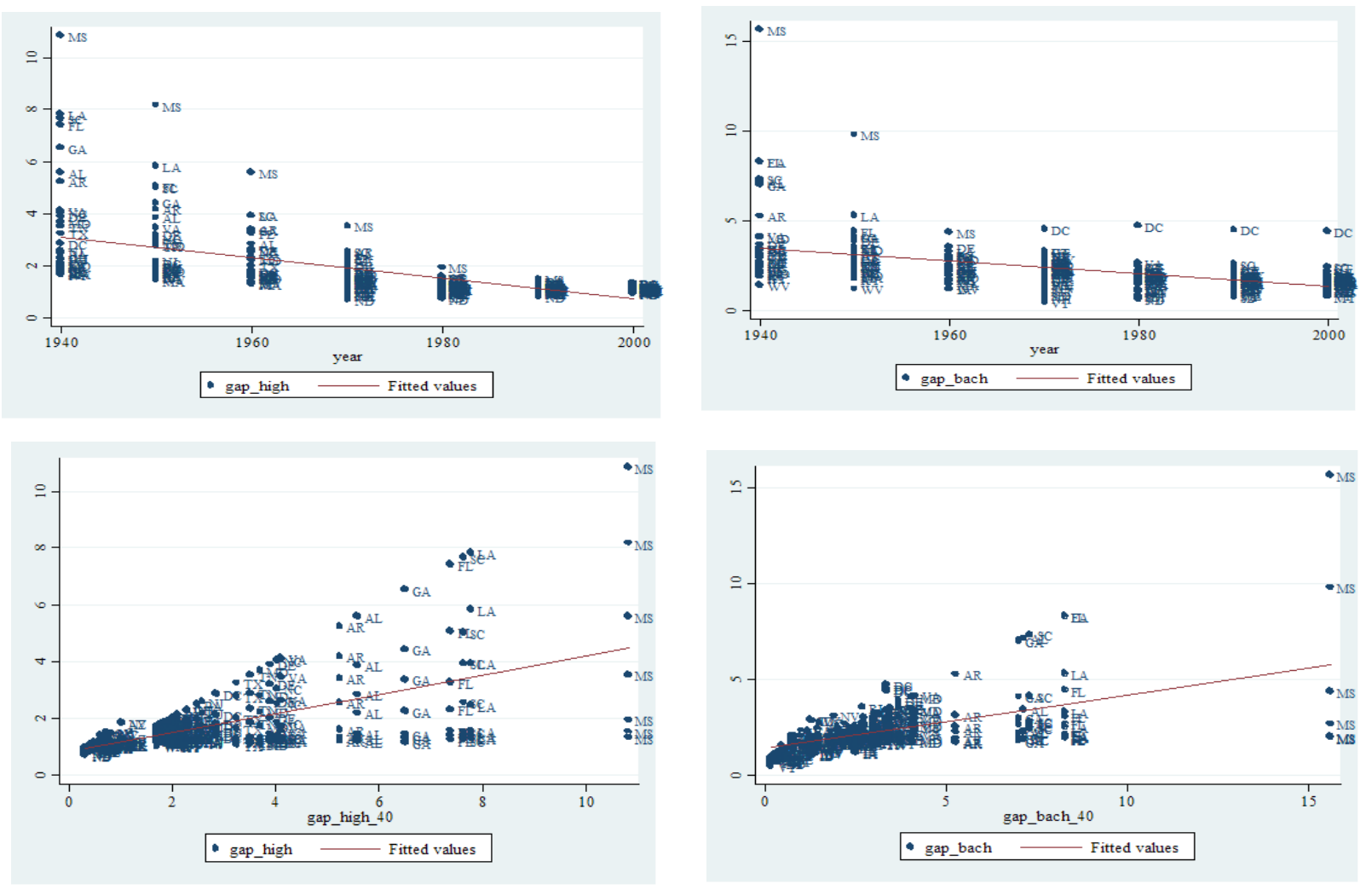

Descriptive statistics for educational gaps (which again we proxy with the white share of educated over the black share of educated, both at the high-school and bachelor level) are reported in Table 2. The table also reports the pairwise correlation between the initial gaps in 1940 and the share of slaves in 1860 over population. At the high-school level the correlation is 0.90 , while the correlation at the college level is almost 0.81 . The large correlation between the share of slaves in 1860 and the initial gap suggests that one could consider the former as a mere proxy for the former. However the association between the two variables requires a more formal inspection.

In Table 3 we start by regressing the educational gap on its initial level in 1940, in a parsimonious specification where we only control for population density as well as region and time fixed effects, in order to use the maximal number of observations. Population density is included as a proxy for prosperity. We use a dummy for Southern States in order to control for structural and political/institutional differences between the North and the South of the US. The Atlantic dummy is entered because there is evidence that the vicinity to the coast, and in particular to the Atlantic Ocean, affects the general level of development. ${ }^{10}$

\footnotetext{
${ }^{10}$ See Lagerlöf (2005) and Rappaport and Sachs (2003) for an analysis of the coastal concentration of economic activity in the US.
} 
Table 2: Descriptive Statistics

\begin{tabular}{|c|c|c|c|c|c|}
\hline \multicolumn{6}{|c|}{ Descriptive Statistics } \\
\hline Variable & Obs & Mean & Std. Dev. & Min & Max \\
\hline Educational Gap 1940 (High-S.) & 297 & 2.789 & 2.340 & 0.303 & 10.840 \\
\hline Educational Gap 1940 (Bachelor) & 297 & 3.225 & 2.819 & 0.163 & 15.638 \\
\hline Slaves/Population 1860 & 336 & 0.115 & 0.180 & 0 & 0.5718 \\
\hline \multicolumn{6}{|c|}{ Pairwise Correlation } \\
\hline & $\begin{array}{c}\text { Gap } 1940 \\
\text { H.S. }\end{array}$ & $\begin{array}{c}\text { Gap } 1940 \\
\text { Bach. }\end{array}$ & \multicolumn{2}{|c|}{$\begin{array}{c}\text { Slaves/Pop. } \\
1860 \\
\end{array}$} & \\
\hline Educational Gap 1940 (High-S.) & 1.0000 & & & & \\
\hline Educational Gap 1940 (Bachelor) & 0.9645 & 1.0000 & & & \\
\hline Slaves/Population 1860 & 0.9023 & 0.8088 & 1.0000 & & \\
\hline
\end{tabular}

Note: See Data Appendix for data sources

Model 1 shows that the gap in high-school education depends significantly on the initial gap. Keeping all the other factors constant, the attainment ratio at the high-school level increases by 0.31 for a unit increase in the initial gap. Model 2 shows results for the gap between shares of population holding a bachelor degree. Decreasing the initial gap for the population holding a bachelor degree by a unit decreases the gap by almost 0.28 . Population density exerts a negative and significant impact on the high-school gap (Model 1), while its effect on the college gap is not significant (Model 2). The dummy for Southern states is significant and negative.

In Models 3 and 4 we replace measures of the initial gap with the share of slaves in 1860 to obtain almost identical estimates given that the share of slaves in 1860 has a significantly positive effect on the racial gaps both at the high-school and bachelor levels. When in Models 5 and 6 we enter the share of slaves together with the initial gaps, the former loses significance, which is not surprising given the pattern of correlation previously described. ${ }^{11}$ The Southern states dummy also loses significance. These findings suggest that the impact of slavery on the evolution of the educational gap may run through its impact on the initial gaps.

Results in Table 3 confirm the sort of cross-state divergence in education between blacks and whites which is illustrated in Figure 1. States which started in 1940 with a larger racial gap in terms of education still show a larger racial educational inequality in 2000, if compared to states in which blacks and whites had similar levels of education. Moreover, slavery appears to affect the

\footnotetext{
${ }^{11}$ In Models 3-6 the number of observations is lower since a few states (e.g., Hawaii, Idaho, Montana) do not appear in the 1860 Census.
} 
educational gaps through their initial levels.

Table 3: The Determinants of the Racial Educational Gap, 1940-2000

\begin{tabular}{|c|c|c|c|c|c|c|}
\hline Estimation Method: Pooled OLS & Model 1 & Model 2 & Model 3 & Model 4 & Model 5 & Model 6 \\
\hline & Gap H.S. & Gap Bach. & Gap H.S. & Gap Bach. & Gap H.S. & Gap Bach. \\
\hline Educational Gap 1940 (High-S.) & $\begin{array}{l}0.306^{* * *} \\
(5.18)\end{array}$ & & & & $\begin{array}{l}0.244^{* * *} \\
(2.91)\end{array}$ & \\
\hline Educational Gap 1940 (Bachelor) & & $\begin{array}{l}0.277^{* * * *} \\
(3.50)\end{array}$ & & & & $\begin{array}{l}0.279 * * * \\
(2.65)\end{array}$ \\
\hline Population Density & $\begin{array}{l}-0.134^{* * *} \\
(-4.11)\end{array}$ & $\begin{array}{l}-0.0743 \\
(-1.43)\end{array}$ & $\begin{array}{l}-0.149 * * * \\
(-3.82)\end{array}$ & $\begin{array}{l}-0.0696 \\
(-1.01)\end{array}$ & $\begin{array}{l}-0.136 * * * \\
(-3.82)\end{array}$ & $\begin{array}{l}-0.0743 \\
(-1.21)\end{array}$ \\
\hline Southern States Dummy & $\begin{array}{l}-0.0629 \\
(-0.50)\end{array}$ & $\begin{array}{l}-0.289 * \\
(-1.75)\end{array}$ & $\begin{array}{l}-0.418^{* *} \\
(-2.04)\end{array}$ & $\begin{array}{l}-0.601^{* *} \\
(-2.12)\end{array}$ & $\begin{array}{l}-0.176 \\
(-1.18)\end{array}$ & $\begin{array}{l}-0.0837 \\
(-0.56)\end{array}$ \\
\hline Atlantic Dummy & $\begin{array}{l}-0.140 \\
(-1.20)\end{array}$ & $\begin{array}{l}0.0867 \\
(0.60)\end{array}$ & $\begin{array}{l}-0.0757 \\
(-0.67)\end{array}$ & $\begin{array}{l}0.0706 \\
(0.46)\end{array}$ & $\begin{array}{l}-0.127 \\
(-1.07)\end{array}$ & $\begin{array}{l}0.0752 \\
(0.54)\end{array}$ \\
\hline Slaves/Population 1860 & & & $\begin{array}{l}4.413^{* * *} \\
(5.33)\end{array}$ & $\begin{array}{l}4.097 * * * \\
(3.51)\end{array}$ & $\begin{array}{l}1.128 \\
(1.38)\end{array}$ & $\begin{array}{l}-0.477 \\
(-0.50)\end{array}$ \\
\hline Constant & $\begin{array}{l}2.434 * * * \\
(5.45)\end{array}$ & $\begin{array}{l}2.082^{* * *} \\
(2.86)\end{array}$ & $\begin{array}{l}3.047 * * * \\
(5.25)\end{array}$ & $\begin{array}{l}2.524 * * \\
(2.35)\end{array}$ & $\begin{array}{l}2.497 * * * \\
(4.79)\end{array}$ & $\begin{array}{l}2.071 * * \\
(2.29)\end{array}$ \\
\hline Time Dummies & Yes & Yes & Yes & Yes & Yes & Yes \\
\hline Observations & 297 & 297 & 258 & 258 & 258 & 258 \\
\hline R-squared & 0.68 & 0.53 & 0.65 & 0.43 & 0.68 & 0.53 \\
\hline
\end{tabular}

*** $\mathrm{p}<0.01,{ }^{* *} \mathrm{p}<0.05,{ }^{*} \mathrm{p}<0.1$. Robust t statistics in parentheses.

In Table 4 we add a full set of state dummies to Models 5 and 6 of Table 3 in order to control for different schooling regulations and provision of public goods at a state level. Previous results are broadly confirmed. The coefficient on the initial gap in high-school education increases from 0.24 to almost 0.4 , while the one for college increases from 0.28 to 0.32 . The high-school gap is now smaller for states along the Atlantic coast, Southern states, and states with a larger population density. 
Table 4: Controlling for State Dummies

\begin{tabular}{|c|c|c|}
\hline Estimation Method: LSDV & Model 1 & Model 2 \\
\hline & Gap H.S. & Gap Bach. \\
\hline Educational Gap 1940 (High-S.) & $\begin{array}{l}0.395^{* *} \\
(2.04)\end{array}$ & \\
\hline Educational Gap 1940 (Bachelor) & & $\begin{array}{l}0.321^{* *} \\
(2.41)\end{array}$ \\
\hline Population Density & $\begin{array}{l}-0.387 * * \\
(-2.49)\end{array}$ & $\begin{array}{l}-0.0632 \\
(-0.32)\end{array}$ \\
\hline Southern States Dummy & $\begin{array}{l}0.645^{*} \\
(1.91)\end{array}$ & $\begin{array}{l}0.538 \\
(1.33)\end{array}$ \\
\hline Atlantic Dummy & $\begin{array}{l}-0.695 * * \\
(-2.05)\end{array}$ & $\begin{array}{l}0.0655 \\
(0.16)\end{array}$ \\
\hline Slaves/Population 1860 & $\begin{array}{l}-1.139 \\
(-0.72)\end{array}$ & $\begin{array}{l}-1.326 \\
(-1.29)\end{array}$ \\
\hline Constant & $\begin{array}{l}6.072 * * * \\
(2.87)\end{array}$ & $\begin{array}{l}1.680 \\
(0.60)\end{array}$ \\
\hline Time Dummies & Yes & Yes \\
\hline State Dummies & Yes & Yes \\
\hline Observations & 258 & 258 \\
\hline R-squared & 0.71 & 0.58 \\
\hline
\end{tabular}

\section{Controlling for Omitted Variable Bias}

Our results from the previous section show that, over the period under consideration, after controlling for a number of key factors, the contemporaneous racial educational gap is largely explained by the initial gap and that slavery may only have an indirect effect on the educational gap through its effect on initial gaps. This suggests that slavery may be excludable in a regression for the educational gap on its initial level, which makes it a reasonable instrument for the latter. However, while it is reasonable to link the initial educational gap to slavery, through the channels documented in Margo (1990), the lack of significance of the slave share variable when entered together with the gap does not per se validate this conjecture. Indeed the slave share in 1860 may be correlated with some other factors which we were not able to control for and which exert a direct effect on the gap. If this were the case, the effect of slavery on the current gap may have been under-estimated. For this reason, in order to control for such a potential bias in this section we use a 2SLS estimator to obtain consistent estimates. 
Even though it is difficult to find an instrument that can provide an exogenous variation in the share of slaves in 1860, we can use information from the Trans-Atlantic Slave Trade Database to generate a suitable instrument for the share of slaves in $1860 .{ }^{12}$ Most of the slaves arrived to the territories that today represent the US between the seventeenth century and first decade of the nineteenth. Overall, the Middle Passage brought an estimated 645,000 slaves, mostly from Africa. Initially most of the slaves were forcibly settled in the coastal Southern colonies, where they were employed primarily in agriculture. It is only in a subsequent phase, between the American Revolution and the Civil War, that the Second Middle Passage relocated around a million slaves toward the inland regions where the plantation economy was developing (Berlin, 2003).

The relocation of slaves in the Second Middle Passage implies that the reasons why slaves were disembarked in certain states were not only economic, but also merely geographic. Thus, we can use the ratio of disembarked slaves in any given state to the total number of slaves disembarked in the US during the TAST as an instrument for the slave share in 1860. The correlation between the two variables is almost 0.49 , which validates the relevance of the instrument. The excludability of the instrument (and therefore its exogeneity) is ensured by the fact that the effect of slavery in 1860 on the educational gap is likely to work through the institution of slavery and therefore through the political economy of Southern states at the end of the nineteenth century. For example, Bertocchi and Dimico (2011b) show that the disenfranchisement of blacks in 1892 in the state of Mississippi (and the consequent adoption of 'separate but equal' school policies) was more severe in counties where blacks represented a credible political threat to the hegemony of white Democrats. This means that the severity of the disenfranchisement schemes introduced at the end of the nineteenth century in the US South and the consequent availability of public school funding for blacks depended heavily on the share of blacks in the post-Reconstruction period, which was in turn largely determined by the share of slaves in 1860. Since it is the institution of slavery that matters for the education of blacks, the share of disembarked slaves coming from Africa should affect educational inequality only through the enforcement of such an institution, since it is difficult to envision any other direct effect of this variable on educational inequality itself.

Figure 2 represents schematically our exclusion restriction. The share of disembarked slaves per state during the TAST (to the total number of disembarked slaves in the US) determined the share of slaves in 1860. The slave share in 1860 had an effect on the enforcement of the institution of slavery and on the extent of disenfranchisement. The latter has affected the educational gap because of its effect on public school funding.

\footnotetext{
${ }^{12}$ Nunn (2008b), Nunn and Wantchekon (2011) and Assunção et al. (2011) also employ the same data.
} 
Figure 2: Causal Effect of the Trans-Atlantic Slave Trade on Educational Gap

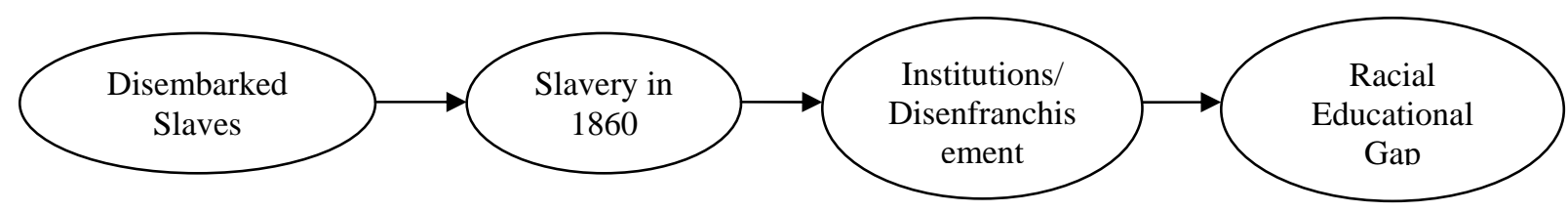

Table 5 reports descriptive statistics for the share of disembarked slaves imported from Africa as well as its correlation with the share of slaves in 1860. On average the share of disembarked slaves per state (to the US total) is equal to 2 percent against an 11.5 percent of the slave population (to the total US population) in 1860. The largest share of slaves (50 percent of the total) disembarked in South Carolina. Virginia came next with 29 percent. South Carolina is also the state with the largest share of slaves in 1860 (57 percent of the total population) followed by Mississippi (almost 55 percent), Louisiana (47 percent), Alabama, Florida, and Georgia (with shares between 44 and 45 percent). ${ }^{13}$ The correlation between the disembarked share and the slave share in 1860 is almost 0.49 which means that even though the Second Middle Passage relocated a large number of slaves there is a large share which remained in the state of arrival. ${ }^{14}$

Table 5: Descriptive Statistics for Disembarked Slaves

\begin{tabular}{|c|c|c|c|c|c|}
\hline \multicolumn{6}{|c|}{ Descriptive Statistics } \\
\hline Variable & Obs & Mean & Std. Dev. & Min & Max \\
\hline Slaves/Population 1860 & 336 & 0.115 & 0.180 & 0 & 0.571 \\
\hline Disembarked Slaves/Total Slaves & 336 & 0.0196 & 0.080 & 0 & 0.504 \\
\hline \multicolumn{6}{|c|}{ Pairwise Correlation } \\
\hline & & /Population 1860 & \multicolumn{3}{|c|}{ Disembarked Slaves/Total Slaves } \\
\hline Slaves/Population 1860 & & 1.0000 & & & \\
\hline Disembarked Slaves/Total Slaves & & 0.4875 & \multicolumn{3}{|c|}{1.000} \\
\hline
\end{tabular}

Note: See Data Appendix for data sources

Table 6 reports 2SLS estimates using the share of disembarked slaves from the TAST Database as an instrument for the share of slaves in $1860 .{ }^{15}$ The partial F-Statistics and the Cragg-Donald FStatistics show that our instrument is a relevant one since it provides sufficiently high correlation

\footnotetext{
${ }^{13}$ See Table A1 in the Table Appendix for details.

${ }^{14}$ The (unreported) correlation of the disembarked slaves share with the educational gap is 0.39 for the high-school level and 0.24 for the bachelor level.

${ }^{15}$ State dummies are omitted because of a collinearity problem.
} 
with the endogenous variable. The second-stage estimates confirm the insignificant effect of the share of slaves on the educational gap (both at the high-school and college level). On the other hand, the initial educational gap for both dependent variables is still significant. Turning to the firststage statistics, the coefficients on the share of disembarked slaves suggest that a one percent increase in the share of slaves imported from Africa increases the share of slaves in 1860 by a percentage which is in the range of 26 to 36 percent.

Table 6: 2SLS Estimates for Slavery

\begin{tabular}{|c|c|c|c|c|}
\hline \multirow{4}{*}{ Estimation Method: 2SLS } & \multicolumn{2}{|c|}{ Second-Stage Estimates } & \multirow{2}{*}{\multicolumn{2}{|c|}{$\begin{array}{c}\text { First-Stage Estimates } \\
\text { Dependent Variable: } \\
\text { Slaves/Population } 1860\end{array}$}} \\
\hline & \multicolumn{2}{|c|}{$\begin{array}{c}\text { Dependent Variables: } \\
\text { Educational Gap }\end{array}$} & & \\
\hline & Model 1 & Model 2 & Model 1 & Model 2 \\
\hline & Gap H.S. & Gap Bach. & Slaves 1860 & Slaves 1860 \\
\hline Educational Gap 1940 (High-S.) & $\begin{array}{l}0.249 * * \\
(2.25)\end{array}$ & & $\begin{array}{l}0.045^{* * *} \\
(21.19)\end{array}$ & \\
\hline Educational Gap 1940 (Bachelor) & & $\begin{array}{l}0.203^{* * *} \\
(2.91)\end{array}$ & & $\begin{array}{l}0.029 * * * \\
(16.50)\end{array}$ \\
\hline Population Density & $\begin{array}{l}-0.136 * * * \\
(-2.61)\end{array}$ & $\begin{array}{l}-0.0664 \\
(-0.94)\end{array}$ & $\begin{array}{l}0.0011 \\
(0.29)\end{array}$ & $\begin{array}{l}-0.002 \\
(-0.48)\end{array}$ \\
\hline Southern States Dummy & $\begin{array}{l}-0.157 \\
(-0.39)\end{array}$ & $\begin{array}{l}-0.666 \\
(-1.27)\end{array}$ & $\begin{array}{l}0.158^{* * *} \\
(14.76)\end{array}$ & $\begin{array}{l}0.206^{* * *} \\
(18.42)\end{array}$ \\
\hline Atlantic Dummy & $\begin{array}{l}-0.128 \\
(-1.27)\end{array}$ & $\begin{array}{l}0.0676 \\
(0.50)\end{array}$ & $\begin{array}{l}-0.022^{* * *} \\
(-2.96)\end{array}$ & $\begin{array}{l}-0.017^{* *} \\
(-2.00)\end{array}$ \\
\hline Slaves/Population 1860 & $\begin{array}{l}1.018 \\
(0.45)\end{array}$ & $\begin{array}{l}2.073 \\
(0.95)\end{array}$ & & \\
\hline Constant & $\begin{array}{l}2.489 * * * \\
(3.02)\end{array}$ & $\begin{array}{l}2.080 * \\
(1.92)\end{array}$ & $\begin{array}{l}-0.076 \\
(-1.28)\end{array}$ & $\begin{array}{l}-0.011 \\
(-0.17)\end{array}$ \\
\hline Time Dummies & Yes & Yes & Yes & Yes \\
\hline Under-Identification Test (Anderson LR Stat) & 35.487 & 50.291 & & \\
\hline Weak Identification Test (Cragg-Donald F-Stat) & 36.247 & 52.944 & & \\
\hline Stock and Yogo (2005) Critical Values (10\%) & 16.38 & 16.38 & & \\
\hline Instrument: Disembarked Slaves/Total Slaves & & & $\begin{array}{l}0.256^{* * *} \\
(6.02)\end{array}$ & $\begin{array}{l}0.355^{* * *} \\
(7.28)\end{array}$ \\
\hline Partial F-Statistics & & & 36.27 & 52.94 \\
\hline Observations & 258 & 258 & 258 & 258 \\
\hline R-squared & 0.68 & 0.51 & 0.89 & 0.92 \\
\hline
\end{tabular}

Next, given that the slave share in 1860 has no direct effect on the educational gap, we can use it as an instrument for the initial gap in order to have consistent estimates of its effect. Table 7 reports 
2SLS estimates for models in which the initial educational gap is instrumented with the slave share in 1860. In the table we also report the first-stage coefficients for the instrument as well as the firststage partial F-Statistics. As expected the share of slaves in 1860 represents a relevant instrument for the educational gap in 1940, which is not surprising given that the correlation between the two variables is close to 0.9. In the first two models the effect of the initial educational gap on the subsequent gap is significant and at the high-school level the coefficient estimate is now larger than the one in the corresponding models estimated by OLS (i.e., Models 1 and 2 in Table 3). The estimated effect of the initial gap decreases when we enter a full set of state dummies. The gap between whites and blacks in 1940 at the college level is now only marginally significant (at a 10 percent) but this may be due to the loss of efficiency of the IV. The gap between whites and black at the high-school level decreases from 0.32 to 0.29 and is still significant at the 1 percent.

To conclude, we find that slavery has no effect on the racial inequality in education other than through its effect on the initial gap in 1940. This finding generates a suitable instrument to investigate whether during the 1940-2000 period racial educational inequality has been persistently shaped by its initial level. Using the 1860 slave share as an instrument, we establish that indeed the initial gap still exerts a significantly positive impact on the subsequent degree of inequality, which means that initial conditions as of 1940 have shaped educational attainment in a persistent fashion. Moreover, this initial inequality can be linked to the legacy of slavery, which confirms the conjecture that current racial educational inequality has indeed deep roots in the history of the country.

\section{Slavery, the Educational Gap, and Economic Growth}

Having established a robust link between slavery and education, we now turn to a broader question. Has slavery slowed down the development process in states which made a larger use of this form of labor force? And, if so, through which channels?

In order to shed light on this issue we first look at a direct effect of slavery on economic growth and then we move forward to evaluate its potential indirect effect, which works through educational inequality between races. More precisely, we assess whether the initial educational gap between blacks and whites can work as a possible channel of transmission. In order to look at these possible direct and indirect effects we proceed in two steps as in the previous section. We start by using a 2SLS estimator to get consistent estimates of the effect of slavery on economic growth. If this effect is found not significant then we can assume that slavery is excludable in a regression for economic 
growth on the initial educational gap. Therefore we can use slavery as an instrument for the initial racial gap in education to get a consistent estimate of the effect of racial education inequality on economic growth. Rates of per capita annual income growth over the 1940-2000 period are computed using first differences for the log of personal per capita income at the state level over the 1930-2000 period. This allows us to construct 10-years episodes of growth over the 1940-2000 period. The data source is the Bureau of Economic Analysis (BEA). ${ }^{16}$

Table 7: 2SLS for the Educational Gap

\begin{tabular}{|c|c|c|c|c|}
\hline \multirow{3}{*}{ Estimation Method: 2SLS } & \multicolumn{4}{|c|}{ Second- Stage Estimates } \\
\hline & \multicolumn{4}{|c|}{ Dependent Variables: Educational Gap } \\
\hline & Model 1 & Model 2 & Model 3 & Model 4 \\
\hline & Gap H.S. & Gap Bach. & Gap H.S. & Gap Bach. \\
\hline Educational Gap 1940 (High School) & $\begin{array}{l}0.328^{* * *} \\
(5.83)\end{array}$ & & $\begin{array}{l}0.289 * * * \\
(3.45)\end{array}$ & \\
\hline Educational Gap 1940 (Bachelor) & & $\begin{array}{l}0.250^{* * *} \\
(3.94)\end{array}$ & & $\begin{array}{l}0.159 * \\
(1.87)\end{array}$ \\
\hline Population Density & $\begin{array}{l}-0.132^{* * *} \\
(-3.66)\end{array}$ & $\begin{array}{l}-0.0738 \\
(-1.23)\end{array}$ & $\begin{array}{l}-0.334^{* * *} \\
(-3.30)\end{array}$ & $\begin{array}{l}0.0730 \\
(0.55)\end{array}$ \\
\hline Southern States Dummy & $\begin{array}{l}-0.0926 \\
(-0.76)\end{array}$ & $\begin{array}{l}-0.138 \\
(-1.05)\end{array}$ & $\begin{array}{l}0.455^{* * *} \\
(3.01)\end{array}$ & $\begin{array}{l}0.192 \\
(0.95)\end{array}$ \\
\hline Atlantic Dummy & $\begin{array}{l}-0.145 \\
(-1.33)\end{array}$ & $\begin{array}{l}0.0747 \\
(0.55)\end{array}$ & $\begin{array}{l}-0.543^{* * *} \\
(-2.83)\end{array}$ & $\begin{array}{l}0.427 \\
(1.58)\end{array}$ \\
\hline Constant & $\begin{array}{l}2.309 * * * \\
(4.31)\end{array}$ & $\begin{array}{l}2.119^{* *} \\
(2.33)\end{array}$ & $\begin{array}{l}5.404^{* * *} \\
(3.79)\end{array}$ & $\begin{array}{l}-0.110 \\
(-0.06)\end{array}$ \\
\hline Under-Identification Test (Anderson LR Stat) & 261.375 & 170.803 & 451.921 & 204.74 \\
\hline Weak Identification Test (Cragg-Donald F-Stat) & 433.255 & 231.864 & 1029.023 & 261.141 \\
\hline Stock and Yogo (2005) Critical Values (10\%) & 16.38 & 16.38 & 16.38 & 16.38 \\
\hline Instrument: Slaves/Population 1860 & $\begin{array}{l}13.449 * * * \\
(14.90)\end{array}$ & $\begin{array}{l}16.410^{* * *} \\
(8.79)\end{array}$ & $\begin{array}{l}10.733^{* * *} \\
(14.60)\end{array}$ & $\begin{array}{l}8.192 * * * \\
(7.59)\end{array}$ \\
\hline Partial F-Statistics (First Stage) & 222.02 & 77.24 & 82.65 & 54.73 \\
\hline State Dummies & No & No & Yes & Yes \\
\hline Time Dummies & Yes & Yes & Yes & Yes \\
\hline Observations & 258 & 258 & 258 & 258 \\
\hline R-squared & 0.68 & 0.52 & 0.71 & 0.57 \\
\hline
\end{tabular}

*** $\mathrm{p}<0.01, * * \mathrm{p}<0.05, * \mathrm{p}<0.1$. Robust t statistics in parentheses.

Educational Gap 1940 is the instrumented variable.

\footnotetext{
${ }^{16}$ BEA also provides data on GDP per capita at the state level but these data are only available starting from 1963 . We use data on personal per capita income because they are available over a longer time span.
} 
Table 8 reports 2SLS estimates. In each model we enter the initial condition, i.e., the lagged level of income per capita, as well as growth determinants such as population growth and the amount of bank deposits per capita as a proxy for saving and therefore investment. ${ }^{17}$ We also enter a proxy for agricultural dependence, which is equal to the ratio of farms to manufacturing establishments, in order to control for potential differences in the production function (see Temple, 2005) and other geographical dummies. Due to data limitations over such a long time horizon our specification is quite parsimonious, but the exogenous variation in the initial gap provided by our instrument should ensure that estimates converge in probability to the true population parameters (conditional on the exogeneity of the instrument) and because of that they should not be affected by the omission of other factors. On the other hand, this parsimonious specification is also shared by similar papers on development and education in the US (e.g., Aghion et al. 2009; Higgins et al., 2006).

In the first two models we look at a possible direct effect of slavery on economic growth. ${ }^{18}$ As in the previous section we use a 2SLS estimator where the share of disembarked slaves in each state during the TAST is employed as an instrument for the share of slaves in 1860. Once again the idea behind its exclusion is that the share of disembarked slaves only has a direct effect on the share of slaves in 1860 and, through the latter, on the consequent political economy of Southern states (e.g., public goods provision) and on economic growth. Other than through this channel we should not expect any direct effect of the disembarked slaves share on economic growth over this time period. We find that in both models (i.e., without or with state dummies) the share of slaves in 1860 has no direct effect on economic growth even though both models are well identified. Incidentally, we also find evidence of convergence and of a positive effect of the amount of deposits per capita, while agricultural dependence exerts a negative effect in Model 2.

Since the share of slaves in 1860 is found to be an insignificant determinant of economic growth we can move forward to the second step. In Models 3 and 4 we use the share of slaves as an instrument for the educational gap between blacks and whites in 1940 to test a potential indirect effect of slavery which works through educational inequality between races. The exclusion restriction is now validated by results from the previous model. The effect of the initial educational gap is significant at the 10 percent level in Model 3 and at the 1 percent level in Model 4 where we enter a full set of state dummies. ${ }^{19}$ On average a unit increase in the educational gap between whites and blacks in 1940 decreases the rate of growth by almost 0.21 percent. Moreover, as expected in both models the

\footnotetext{
${ }^{17}$ As for GDP per capita, BEA provides data on investment to GDP only starting from 1963.

${ }^{18}$ The proxy for the educational gap in the first two models is dropped because of the weak relevance of the instrument in the presence of the gap.

${ }^{19}$ Here we only report estimates for the racial gap at the high-school level. Analogous estimates at the college level are reported in Table A4 in the Table Appendix.
} 
higher is the state's level of income the lower is the rate of economic growth in the following decades. The amount of deposits per capita also spurs economic growth while the level of agricultural dependence lowers it.

Table 8: Economic Growth, Slavery, and the Educational Gap

\begin{tabular}{|c|c|c|c|c|}
\hline \multirow{3}{*}{ Estimation Method: 2SLS } & \multicolumn{4}{|c|}{ Second-Stage Estimates } \\
\hline & \multicolumn{4}{|c|}{ Dependent Variable: Per Capita Economic Growth } \\
\hline & Model 1 & Model 2 & Model 3 & Model 4 \\
\hline Slaves/Population 1860 & $\begin{array}{l}0.0142 \\
(0.96)\end{array}$ & $\begin{array}{l}-0.0197 \\
(-1.39)\end{array}$ & & \\
\hline Educational Gap 1940 (High School) & & & $\begin{array}{l}-0.000527 * \\
(-1.77)\end{array}$ & $\begin{array}{l}-0.00209 * * * \\
(-3.61)\end{array}$ \\
\hline Income per Capita ( $\mathrm{t}$ - 1) (Log) & $\begin{array}{l}-0.0243^{* * *} \\
(-4.83)\end{array}$ & $\begin{array}{l}-0.0465 * * * \\
(-9.39)\end{array}$ & $\begin{array}{l}-0.0306^{* * *} \\
(-8.68)\end{array}$ & $\begin{array}{l}-0.0502 * * * \\
(-10.82)\end{array}$ \\
\hline Population Growth & $\begin{array}{l}0.0586 \\
(1.39)\end{array}$ & $\begin{array}{l}0.0421 \\
(0.61)\end{array}$ & $\begin{array}{l}0.0283 \\
(0.78)\end{array}$ & $\begin{array}{l}-0.0191 \\
(-0.30)\end{array}$ \\
\hline Bank Deposits per Capita & $\begin{array}{l}0.00247^{* *} \\
(2.36)\end{array}$ & $\begin{array}{l}0.00274 * * \\
(2.01)\end{array}$ & $\begin{array}{l}0.00172 * \\
(1.92)\end{array}$ & $\begin{array}{l}0.00179 * \\
(1.68)\end{array}$ \\
\hline Atlantic Dummy & $\begin{array}{l}0.00132 \\
(1.21)\end{array}$ & $\begin{array}{l}0.000650 \\
(0.33)\end{array}$ & $\begin{array}{l}0.00266^{* * *} \\
(2.78)\end{array}$ & $\begin{array}{l}0.00182 \\
(0.99)\end{array}$ \\
\hline Southern States Dummy & $\begin{array}{l}-0.00472 \\
(-1.19)\end{array}$ & $\begin{array}{l}0.00720 \\
(1.57)\end{array}$ & $\begin{array}{l}0.000168 \\
(0.15)\end{array}$ & $\begin{array}{l}0.00624^{* * *} \\
(3.05)\end{array}$ \\
\hline Agricultural Dependence & $\begin{array}{l}-0.000714 \\
(-0.19)\end{array}$ & $\begin{array}{l}-0.00977 * * * \\
(-2.59)\end{array}$ & $\begin{array}{l}-0.00594^{* *} \\
(-2.07)\end{array}$ & $\begin{array}{l}-0.0165^{* * *} \\
(-6.40)\end{array}$ \\
\hline Constant & $\begin{array}{l}0.260 * * * \\
(5.20)\end{array}$ & $\begin{array}{l}0.476^{* * *} \\
(9.43)\end{array}$ & $\begin{array}{l}0.330 * * * \\
(9.71)\end{array}$ & $\begin{array}{l}0.524 * * * \\
(11.27)\end{array}$ \\
\hline Under-Identification Test (Anderson LR Stat) & 25.500 & 85.948 & 272.869 & 317.468 \\
\hline Weak Identification Test (Cragg-Donald F-Stat) & 25.367 & 84.502 & 464.809 & 522.612 \\
\hline Stock and Yogo (2005) Critical Values (10\%) & 16.38 & 16.38 & 16.38 & 16.38 \\
\hline Instrument 1: Disembarked Slaves/Total Slaves & $\begin{array}{l}0.312^{* * * *} \\
(5.46)\end{array}$ & $\begin{array}{l}0.545^{* * * *} \\
(8.86)\end{array}$ & & \\
\hline Instrument 2: Slaves/Population 1860 & & & $\begin{array}{l}15.434^{* * * *} \\
(16.12)\end{array}$ & $\begin{array}{l}11.279 * * * \\
(18.55)\end{array}$ \\
\hline Partial F-Statistics (First Stage) & 29.82 & 78.47 & 259.81 & 344.03 \\
\hline State Dummies & No & Yes & No & Yes \\
\hline Time Dummies & Yes & Yes & Yes & Yes \\
\hline Observations & 288 & 288 & 252 & 252 \\
\hline R-squared & 0.95 & 0.96 & 0.96 & 0.96 \\
\hline
\end{tabular}

Even though in Table 8 we use personal income per capita at current US dollars to compute the annual rate of growth, this should not represent a problem given that the time dummies capture the effect of inflation. However as a robustness check we also use data on the Consumer Price Index (CPI) from the Bureau of Labour Statistics to convert personal income at current prices into 
personal income at constant 2000 US dollars. Table A2 in the Table Appendix shows descriptive statistics for both the current- and the constant-prices versions of personal income per capita. Average personal income per capita at current prices is $\$ 8,318$ and its average growth rate over the 60 years period is equal to 5.7 percent with a maximal rate of growth of 13.7. When converted into constant 2000 US\$ average personal income per capita is \$15,909 and its average growth rate over the period is 2.4 percent with a maximal rate of growth of 8.3. In Table A3 in the Table Appendix we replicate Table 8 using the rate of growth of per capita income at constant prices and results are exactly the same given that time dummies in Table 8 capture the changes in the CPI.

As a further check, in Table A4 in the Table Appendix we also test the effect of the educational gap at the bachelor level, rather than at the high-school level as in Table 8. We obtain similar results, which is not surprising given that the exogenous variation provided by slavery makes the two predicted variables quite correlated.

To conclude, we find no consistent evidence of a direct influence of slavery on income growth, even after instrumenting it with information about disembarked slaves during the TAST. This finding is not only interesting per se, but also carries the advantage of generating a suitable instrument to investigate whether racial educational inequality has had any influence on growth during the 19402000 period. Using the 1860 slave share as an instrument, we establish that indeed the initial gap negatively affects growth. In other words, in 1940 the degree of racial educational inequality is still determined by the 1860 slave share. It is through this channel that slavery hampers economic development.

\section{Conclusion}

The legacy of slavery still looms over American society, but debate arose over whether this legacy can still exert a measurable influence on the economic and social achievements of blacks. This paper shows that the contemporaneous degree of racial inequality in education is indeed affected by slavery through its effect on the level of the gap at the eve of World War Two. This channel of influence is identified through a two-step instrumentation strategy that allows us to obtain consistent estimates of the persistence of racial educational inequality throughout the 1940-2000 period. Over the same period, we also find that income growth is negatively affected by the initial educational disparities between blacks and whites, which uncovers a negative influence of slavery on development that runs through the accumulation of human capital. Therefore, our investigation on the evolution and perpetuation of racial inequality in the US confirms, on the one hand, how 
deeply are they rooted in the country's history and, on the other, identifies through which channel they still manifest themselves on contemporaneous outcomes.

\section{References}

Aghion, P., Boustan, L., Hoxby, C., Vandenbussche, J., 2009. The Causal Impact of Education on Economic Growth: Evidence from the United States. Mimeo. Harvard University.

Assunção, J. J., Goulart, T. F., Soares, R. R., 2011. A Note on Slavery and the Roots of Inequality. Mimeo. Pontifical Catholic University of Rio de Janeiro.

Barro, R. J., Sala-i-Martin, X., 1991. Convergence across States and Regions. Brookings Papers on Economic Activity 1, 107-158.

Berlin, I., 2003. Generations of Captivity: A History of African American Slaves. Harvard University Press. Cambridge.

Bertocchi, G.., Dimico, A., 2011a. Slavery, Education, and Inequality, CEPR Discussion Paper No. 8073.

Bertocchi, G.., Dimico, A., 2011b. Race v. Suffrage: The Determinants of Development in Mississippi. CEPR Discussion Paper No. 8589.

Cameron, S. V., Heckman, J. J., 2001. The Dynamics of Educational Attainment for Blacks, Hispanics, and Whites. Journal of Political Economy 109, 455-499.

Card, D., Krueger, B. D., 1992. School Quality and Black-White Relative Earnings: A Direct Assessment. Quarterly Journal of Economics 107, 151-200.

Collins, W. J., Margo, R. A., 2006. Historical Perspectives on Racial Differences in Schooling in the United States. In Hanushek, E., Welch, F. (eds.). Handbook of the Economics of Education. Elsevier. New York. 107-154.

Eltis, D., 2008. A Brief Overview of the Trans-Atlantic Slave Trade. Voyages: The Trans-Atlantic Slave Trade Database. http://www.slavevoyages.org/tast/assessment/essays-intro-01.faces (accessed April 27, 2008).

Engerman, S. L., Sokoloff, K. L., 2005. Institutional and Non-Institutionals Explanations of Economic Differences. In Menard, C., Shirley, M. M. (eds.). Handbook of New Institutional Economics. Springer. Dordrecht. 639-665.

Fishback, P. V., Baskin, J. H., 1991. Narrowing the Black-White Gap in Child Literacy in 1910: The Roles of School Inputs and Family Inputs. Review of Economics and Statistics 73, 725-728.

Frank, M., 2009. Inequality and Growth in the United States: Evidence from a New State-Level Panel of Income Inequality Measures. Journal of Economic Inquiry 47, 55-68.

Galor, O., Moav, O., Vollrath, D., 2009. Inequality in Landownership, the Emergence of HumanCapital Promoting Institutions, and the Great Divergence. Review of Economic Studies 76, 143-179. 
Goldin, C., 1998, America's Graduation from High School: The Evolution and Spread of Secondary Schooling in the Twentieth Century. Journal of Economic History 58, 345-374.

Goldin, C., Katz, L. F., 2001. The Legacy of U.S. Educational Leadership: Notes on Distribution and Economic Growth in the 20th Century. American Economic Review 91, 18-23.

Goldin, C., Katz, L. F., 1999. The Shaping of Higher Education: The Formative Years in the Unites States, 1890 to 1940. Journal of Economic Perspectives 13, 37-62.

Goldin, C., Margo, R. A., 1992. The Great Compression: The US Wage Structure at Mid-Century. Quarterly Journal of Economics 107, 1-34.

Heckman, J. J., 1990. The Central Role of the South in Accounting for Economic Progress of Black Americans. American Economic Review 80, 242-246.

Higgins, M. J., Levy, D., Young, A. T., 2006. Growth and Convergence Across the United States: Evidence from the County-Level Data. Review of Economics and Statistics 88, 671-681.

Jones, C. I., 2002. Sources of U.S. Economic Growth in a World of Ideas. American Economic Review 92, 220-239.

Lagerlöf, N., 2005. Geography, Institutions, and Growth: The United States as a Microcosm. Mimeo. York University.

Margo, R. A., 1990. Race and Schooling in the South, 1880-1950: An Economic History. University of Chicago Press. Chicago.

Mitchener, K. J., McLean, I. W., 2003. The Productivity of U.S. States since 1880. Journal of Economic Growth 8, 73-114.

Naidu, S., 2010. Suffrage, Schooling, and Sorting in the Post-Bellum U.S. South. Mimeo. Harvard University.

Neal, D., 2006. Why Has Black-White Skill Convergence Stopped? In Hanushek, E., Welch, F. (eds.). Handbook of Economics of Education. Vol. 1. Ch. 9. North-Holland. Amsterdam. 511-576.

Nunn, N., 2008a. Slavery, Inequality, and Economic Development in the Americas: An Examination of the Engerman-Sokoloff Hypothesis. In Helpman, E. (ed.). Institutions and Economic Performance. Harvard University Press. Cambridge. 148-180.

Nunn, N., 2008b. The Long-Term Effects of Africa's Slave Trades. Quarterly Journal of Economics 123, 139-176.

Nunn, N., Wantchekon , L., 2011. The Slave Trade and the Origins of Mistrust in Africa. American Economic Review. Forthcoming.

Orazem, P. F., 1987. Black-White Differences in Schooling Investment and Human Capital Production in Segregated Schools. American Economic Review 77, 714-723.

Panizza, U., 2002. Income Inequality and Economic Growth: Evidence from American Data. Journal of Economic Growth 7, 25-41. 
Partridge, M. 1997. Is Inequality Harmful for Growth? Comment. American Economic Review 87, 1019-1032.

Rappaport, J., Sachs, J. D., 2003. The United States as a Coastal Nation. Journal of Economic Growth 8, 5-46.

Sacerdote, B., 2005. Slavery and the Intergenerational Transmission of Human Capital. Review of Economics and Statistics 87, 217-234.

Smith, J. P., 1984. Race and Human Capital. American Economic Review 74, 685-98.

Smith, J. P., Welch, F. R., 1989. Black Economic Progress After Myrdal. Journal of Economic Literature 27, 519-564.

Temple, J., 2005. Dual Economy Models: A Primer For Growth Economists. Manchester School 73, 435-478.

Welch, F., 1973. Black-White Differences in Returns to Schooling. American Economic Review 63, 893-907. 
Table Appendix

Table A1: Slaves/Population in 1860 and Disembarked Slaves/Total Slaves, by State

\begin{tabular}{|c|c|c|c|}
\hline State & Slaves/Population 1860 & $\begin{array}{l}\text { Disembarked Slaves/ } \\
\text { Total Slaves }\end{array}$ & Freq. \\
\hline AL & .45123371 & .0004817 & 8 \\
\hline AR & .25517282 & 0 & 8 \\
\hline CA & 0 & 0 & 8 \\
\hline $\mathrm{CO}$ & 0 & 0 & 8 \\
\hline CT & 0 & 0 & 8 \\
\hline DC & .04242142 & 0 & 8 \\
\hline $\mathrm{DE}$ & .01602267 & 0 & 8 \\
\hline FL & .43970403 & .01835292 & 8 \\
\hline GA & .43715513 & .04243812 & 8 \\
\hline IA & 0 & 0 & 8 \\
\hline IL & 0 & 0 & 8 \\
\hline IN & 0 & 0 & 8 \\
\hline KS & .00001866 & 0 & 8 \\
\hline KY & .19510783 & 0 & 8 \\
\hline LA & .46853822 & .03498485 & 8 \\
\hline MA & 0 & .00081014 & 8 \\
\hline MD & .12690361 & .06168001 & 8 \\
\hline $\mathrm{ME}$ & 0 & 0 & 8 \\
\hline MI & 0 & 0 & 8 \\
\hline $\mathrm{MN}$ & 0 & 0 & 8 \\
\hline MO & .09723336 & 0 & 8 \\
\hline MS & .55178595 & .00939685 & 8 \\
\hline NC & .3335197 & .00849551 & 8 \\
\hline $\mathrm{NE}$ & .00052009 & 0 & 8 \\
\hline NH & 0 & 0 & 8 \\
\hline NJ & .00002678 & .00115609 & 8 \\
\hline NM & 0 & 0 & 8 \\
\hline NV & 0 & 0 & 8 \\
\hline NY & 0 & .01040043 & 8 \\
\hline $\mathrm{OH}$ & 0 & 0 & 8 \\
\hline OR & 0 & 0 & 8 \\
\hline PA & 0 & .00196623 & 8 \\
\hline RI & 0 & .00126557 & 8 \\
\hline SC & .57183659 & .50423902 & 8 \\
\hline SD & 0 & 0 & 8 \\
\hline $\mathrm{TN}$ & .24844004 & 0 & 8 \\
\hline TX & .30215403 & .00826419 & 8 \\
\hline UT & .00072009 & 0 & 8 \\
\hline VA & .30749825 & .29606843 & 8 \\
\hline VT & 0 & 0 & 8 \\
\hline WA & 0 & 0 & 8 \\
\hline WI & 0 & 0 & 8 \\
\hline Total & .11538126 & .02380953 & 336 \\
\hline
\end{tabular}

Note: In New Jersey a few colored apprentices for life remained after an act to abolish slavery was passed on April 18, 1846. In the 1860 census, these apprentices are classified as slaves. In Kansas, Nebraska and Utah slavery was still permitted though they were not slave states. 
Table A2: Personal Income per Capita at Current and Constant Prices

\begin{tabular}{llllll}
\hline Variable & Obs & Mean & Std. Dev. & Min & Max \\
\hline P.C. Income at Current US\$ & & & & & \\
P.C. Income at Constant 2000 US\$ & 404 & $8,318.017$ & $10,004.68$ & 197 & 41920 \\
P.C. Income Growth at Current US\$ & 404 & $15,909.65$ & $8,486.825$ & $2,031.07$ & 41920 \\
P.C. Income Growth at Constant 2000 US\$ & 353 & .0575348 & .0320738 & -.0174814 & .1379085 \\
\hline
\end{tabular}

Table A3: Economic Growth at Constant Prices

\begin{tabular}{|c|c|c|}
\hline & \multicolumn{2}{|c|}{ Second-Stage Estimates } \\
\hline \multirow[t]{2}{*}{ Estimation Method: 2SLS } & \multicolumn{2}{|c|}{ Dependent Variable: Per Capita Economic Growth } \\
\hline & Model 1 & Model 2 \\
\hline Slaves/Population 1860 & $\begin{array}{l}-0.0197 \\
(-1.39)\end{array}$ & \\
\hline Educational Gap 1940 (High School) & & $\begin{array}{l}-0.00209 * * * \\
(-3.61)\end{array}$ \\
\hline Income per Capita (t - 1) (Log) & $\begin{array}{l}-0.0465^{* * * *} \\
(-9.39)\end{array}$ & $\begin{array}{l}-0.0502 * * * \\
(-10.82)\end{array}$ \\
\hline Population Growth & $\begin{array}{l}0.0421 \\
(0.61)\end{array}$ & $\begin{array}{l}-0.0191 \\
(-0.30)\end{array}$ \\
\hline Bank Deposits per Capita (Log) & $\begin{array}{l}0.00274 * * \\
(2.01)\end{array}$ & $\begin{array}{l}0.00179 * \\
(1.68)\end{array}$ \\
\hline Atlantic Dummy & $\begin{array}{l}0.000650 \\
(0.33)\end{array}$ & $\begin{array}{l}0.00182 \\
(0.99)\end{array}$ \\
\hline Southern States Dummy & $\begin{array}{l}0.00720 \\
(1.57)\end{array}$ & $\begin{array}{l}0.00624 * * * \\
(3.05)\end{array}$ \\
\hline Agricultural Dependence & $\begin{array}{l}-0.00977^{* * *} \\
(-2.59)\end{array}$ & $\begin{array}{l}-0.0165^{* * *} \\
(-6.40)\end{array}$ \\
\hline Constant & $\begin{array}{l}0.461^{* * *} \\
(8.91)\end{array}$ & $\begin{array}{l}0.510^{* * * *} \\
(10.68)\end{array}$ \\
\hline Under-Identification Test (Anderson LR Stat) & 85.949 & 317.449 \\
\hline Weak Identification Test (Cragg-Donald F Stat) & 84.502 & 522.612 \\
\hline Stock and Yogo (2005) Critical Values (10\%) & 16.38 & 16.38 \\
\hline Instrument 1: Disembarked Slaves/Total Slaves & $\begin{array}{l}0.545^{* * *} \\
(8.86)\end{array}$ & \\
\hline Instrument 2: Slaves/Population 1860 & & $\begin{array}{l}11.273^{* * *} \\
(18.55)\end{array}$ \\
\hline Partial F-Statistics (First Stage) & 78.47 & 344.03 \\
\hline State Dummies & Yes & Yes \\
\hline Time Dummies & Yes & Yes \\
\hline Observations & 288 & 252 \\
\hline R-squared & 0.78 & 0.80 \\
\hline
\end{tabular}

*** $\mathrm{p}<0.01,{ }^{* *} \mathrm{p}<0.05, * \mathrm{p}<0.1$. Robust $\mathrm{t}$ statistics in parentheses. 
Table A4: Economic Growth, Slavery, and the College Gap

\begin{tabular}{|c|c|c|}
\hline & \multicolumn{2}{|c|}{ Second- Stage Estimates } \\
\hline \multirow[t]{2}{*}{ Estimation Method: 2SLS } & \multicolumn{2}{|c|}{ Dependent Variable: Per Capita Economic Growth } \\
\hline & Model 1 & Model 2 \\
\hline Educational Gap 1940 (Bachelor) & $\begin{array}{l}-0.000415^{*} \\
(-1.76)\end{array}$ & $\begin{array}{l}-0.00256^{* * *} \\
(-3.54)\end{array}$ \\
\hline Income per Capita (t - 1) (Log) & $\begin{array}{l}-0.0303 * * * \\
(-8.80)\end{array}$ & $\begin{array}{l}-0.0491^{* * *} \\
(-10.77)\end{array}$ \\
\hline Population Growth & $\begin{array}{l}0.0245 \\
(0.68)\end{array}$ & $\begin{array}{l}-0.0547 \\
(-0.80)\end{array}$ \\
\hline Bank Deposits per Capita (Log) & $\begin{array}{l}0.00176 * \\
(1.93)\end{array}$ & $\begin{array}{l}0.00171 \\
(1.62)\end{array}$ \\
\hline Atlantic Dummy & $\begin{array}{l}0.00252 * * * \\
(2.70)\end{array}$ & $\begin{array}{l}0.00292 \\
(1.47)\end{array}$ \\
\hline Southern States Dummy & $\begin{array}{l}-7.00 \mathrm{e}-05 \\
(-0.07)\end{array}$ & $\begin{array}{l}0.00604 * * * \\
(2.96)\end{array}$ \\
\hline Agricultural Dependence & $\begin{array}{l}-0.00572 * * \\
(-2.04)\end{array}$ & $\begin{array}{l}-0.0168 * * * \\
(-6.29)\end{array}$ \\
\hline Constant & $\begin{array}{l}0.327^{* * * *} \\
(9.93)\end{array}$ & $\begin{array}{l}0.516^{* * *} \\
(11.14)\end{array}$ \\
\hline Under-Identification Test (Anderson LR Stat) & 266.880 & 129.557 \\
\hline Weak Identification Test (Cragg-Donald F-Stat) & 189.516 & 139.137 \\
\hline Stock and Yogo (2005) Critical Values (10\%) & 16.38 & 16.38 \\
\hline Instrument: Slaves/Population 1860 & $\begin{array}{l}19.614^{* * *} \\
(10.17)\end{array}$ & $\begin{array}{l}9.217^{* * * *} \\
(10.29)\end{array}$ \\
\hline Partial F-Statistics (First Stage) & 103.41 & 105.95 \\
\hline State Dummies & Yes & Yes \\
\hline Time Dummies & Yes & Yes \\
\hline Observations & 252 & 252 \\
\hline R-squared & 0.96 & 0.96 \\
\hline
\end{tabular}

*** $\mathrm{p}<0.01,{ }^{* *} \mathrm{p}<0.05,{ }^{*} \mathrm{p}<0.1$. Robust $\mathrm{t}$ statistics in parentheses. 


\section{Data Appendix}

The following datasets have been used:

a) Measuring America: The Decennial Censuses from 1790 to 2000 (http://www.census.gov/prod/www/abs/decennial/) is used for the following variables: Total slaves number in 1860, total population in 1860, and shares of whites and blacks with either a high-school diploma or a bachelor degree

b) Data on personal per capita income from 1930 to 2000 is collected from the Bureau of Economic Analysis (www.bea.gov). Historical data on inflation are collected from the Bureau of Labour Statistics (http://www.bls.gov/).

c) Data on number of farms and manufacturing establishments and on bank deposits are collected from the County and City Data Book downloaded from the Inter-University Consortium for Political and Social Studies (http://www.icpsr.umich.edu/).

d) Geographical dummy variables are constructed using the US Census regional classification.

e) Data on disembarked slaves are downloaded from the Trans-Atlantic Slave Trade Database (see Eltis, D., 2008. A Brief Overview of the Trans-Atlantic Slave Trade. Voyages: The Trans-Atlantic Slave Trade Database, http://www.slavevoyages.org/tast/assessment/essays-intro-01.faces). 